\title{
Effects of Organic and Inorganic Fertilizers on the Growth of Senecio biafrae (WOROWO) OLIVE \& HIERN
}

\section{${ }^{* 1}$ AKINTOLA, OO; ${ }^{1}$ ABIOLA, IO; ${ }^{1}$ AKINOLA, OO; ${ }^{2}$ BABATUNDE, KO; ${ }^{1}$ EKAUN, AA; ${ }^{1}$ OLAJIIRE-AJAYI, BL}

\author{
${ }^{1}$ Federal College of Forestry, Ibadan Oyo State, Nigeria \\ ${ }^{2}$ Federal College of Widlife Management, New-Bussa, Niger State, Nigeria \\ *Corresponding Author Email: toyinakintola73@ gmail.com
}

\begin{abstract}
Soils have shown a negative balance in nutrient budget which poses a great threat to sustainable soil management for increase in growth and crop yield. This study thus investigated the effects of organic and inorganic fertilizers on the growth of Senecio biafrae (Oliv. \&Hiern). Topsoil, organic (poultry manure) and inorganic fertilizers (NPK 15:15:15) were used. The fertilizers were weighed and applied to the soil at $5 \mathrm{~g}, 10 \mathrm{~g}, 15 \mathrm{~g}$ each; control topsoil without application of fertilizers and were replicated five times. Growth parameters including height, number of leaves and stem diameter were taken weekly for the period of the experiment. Application of poultry manure and NPK fertilizer had significant effects on all the growth parameters considered. The application of poultry manure resulted into significant increase in the growth parameters towards the latter part of the study. This study has shown that organic manure has great potential for improving soil productivity and plant growth
\end{abstract}

\section{DOI:https://dx.doi.org/10.4314/jasem.v25i2.2}

Copyright: Copyright (C) 2021 Akintola et al. This is an open access article distributed under the Creative Commons Attribution License (CCL), which permits unrestricted use, distribution, and reproduction in any medium, provided the original work is properly cited.

Dates: Received: 12 December 2020; Revised: 26 January 2021; Accepted: 12 February 2021

Keywords: Senecio biafrae, investigate, organic, inorganic, plant yield

Crop productivity is remarkably influenced by nutrients management (Dantata, 2011). Soils have shown a negative balance in nutrient budget which poses a great threat for sustainability of soil management, increase in growth and crop yield (FAO, 2004). Different sources of soil fertility, improvement and management strategies are thus needed for sustainability of soil productivity and subsequent increase in crop growth and yield. Soil fertility is strategically and conventionally replenishing by the application of nutrients in form of either organic or inorganic manure. The application of inorganic fertilizers is commonly regarded as the most dynamic method to improve soil fertility and crop productivity (Chen et al., 2017). Although, an outsized quantity of inorganic fertilizers has been used worldwide to increase crop yield, however, the long-term unreasonable application of chemical fertilizers has resulted in serious adverse effects on the physicochemical properties of soil, such as the degradation of soil organic carbon and soil acidification (Chang et al., 2007; Gong et al., 2008; Cui et al., 2018). Environmental pollution caused by the extremely use of inorganic fertilizers is at alarming rate, thus the effectual and environmentally-friendly fertilization regimes should be called for (Ning et al., 2017). Organic fertilizers are rich in nutrients mainly derived from animal manure and crop straws, which are agricultural waste. It has been demonstrated that use of organic inputs such as crop residues, manures and compost has great potential for improving soil productivity and crop yield through improvement of the physical, chemical and microbiological properties of the soil as well as nutrient supply (Dauda et al., 2008; Bakht et al., 2009; Sun et al., 2015; Zhang et al., 2016; Li et al., 2017). Moreover, the fertilizer efficiency of organic factors is more lasting and creates a healthy environment for the soil over a long period of time, while inorganic fertilizers rapidly perform better than organic manure but fail to create a sustainable environment (Makinde et al.,2007). Use of inorganic fertilizers for crops is not so good for health because of residual effects but in the case of organic fertilizers such problems do not arise but rather increases the productivity of soil as well as crop quality and yield (Makinde et al., 2007). In Nigeria, many farmers resort to the use of inorganic fertilizers than the use organic manure. However, farmers are now showing interest in organic farming because they are more aware about the residual effect of chemical substances used in the crop field and their degrading impact on the environment. Besides, the excess application of inorganic fertilizer also causes hazard to public health. The combined application of organic 
and inorganic fertilizer can increase the yield as well as keep the environment safe and healthy. Studies have shown that the combined use of organic and mineral fertilizers increases crop yield than individual usage (Prasithikhet et al., 1993; Palm 1995) but not much research has been conducted on the extent to which organic and inorganic manure affect growth and yield of crops. Senecio biafrae (Oliv. \&Hiern) which is in the family of compositae belong to the group of vegetables that grow in large quantity as undercover in tree crop plantation. It is a climbing herb of secondary jungle that is commonly found on roadsides, waste places and disturbed land. The plant is locally called worowo in Yoruba and Ota eke in igbo. It is a tropical plant that is found in Nigeria, Ghana, Benin, Sierra Leone, Cameroon and Gabon (Adebooye, 2004). The plant has succulent green leaves and stems which can be eaten as spinach; extracts from the leaves can be taken as juice and can as well be applied to fresh wounds or cuts as styptic in the rural area for man and animal usage (Adelakun et al., 2018). In the past, farmers rely solely on organic manures for crops that proved good for soil health but were slow in response to crop yields thus insufficient to meet the food demand for ever increasing population. Swift economic development has now led the farmers to use mineral fertilizers as they are more economical, affordable, easy to use and quick in response. However, their intensive application is leading to land degradation, deteriorated soil health and leaching of nutrients into the underground water thereby posing environmental risks to human and animal health (Mahmood et al., 2017). Thus, there is need to depict a balance between organic and inorganic extremities that may sustain food availability without deteriorating soil fertility and productivity. Thus, this study was conducted to evaluate the effects of organic and inorganic manure on the growth performance of Seneciobiafrae (Oliv. \&Hiern).

\section{MATERIALS AND METHODS}

A pot experiment was carried out in screen house of Forestry Technology Department, Federal College of Forestry, Ibadan, Oyo state. The experimental site lies between Latitude $7^{0} 26^{\prime} \mathrm{N}$ and Longitude $3^{0} 54^{\prime} \mathrm{E}$. The climate of the area is tropical. The annual rainfall ranges from $1400 \mathrm{~mm}-1500 \mathrm{~mm}$ and average relative humidity of about $65 \%$, the average temperature is $31.8^{\circ} \mathrm{C}$ (FRIN Meteorological Station, 2015). Senecio biafrae seeds were gotten from seed section of Forestry Research Institute of Nigeria (FRIN), Ibadan while the topsoil was collected at the Gmelina arborea plantation within the premises of Federal College of Forestry, Ibadan. Soil sample was air-dried and sieved using $2 \mathrm{~mm}$ sieve to remove stones, roots and other materials that may be detrimental to the emergence of the young plants from the seeds.

The fertilizers used in this work are poultry manure and NPK (15:15:15). The polythene pots $(30 \mathrm{~cm} \mathrm{x}$ $15 \mathrm{cn}$ ) were perforated and filled with $5 \mathrm{~kg}$ of topsoil. The poultry manure was ground into powdery form and sieved prior to weighing and mixing with the soil. Each of the fertilizers weighing $5 \mathrm{~g}, 10 \mathrm{~g}$ and $15 \mathrm{~g}$ were mixed with the soil in the polythene pots and replicated five times. Seven treatments (T0, control; $\mathrm{T} 1$, top soil $+5 \mathrm{~g}$ of poultry manure; $\mathrm{T} 2$, top soil $+10 \mathrm{~g}$ of poultry manure; $\mathrm{T} 3$, top soil $+15 \mathrm{~g}$ of poultry manure; T4, top soil+5g of NPK (15:15:15); T5, top soil+10g of NPK $(15: 15: 15)$ and T6, top soil+15g of NPK $(15: 15: 15))$ were used in this study with the control (without fertilizer), thus making a total of thirty-five polythene pots used. The fertilizers were mixed 3days prior to sowing the seeds. 70 healthy seedlings were picked from germination boxes and transplanted into the polythene pots. The pots were arranged in a completely randomized design and the experiment lasted for 8 weeks ( 2 months). Growth parameters such as plant height, stem diameter and leaf production were assessed weekly for three months. Data were subjected to one-way analysis of variance to compare the effect of the different treatments on the early growth characteristics of S. biafrae.

\section{RESULTS AND DISCUSSION}

The variation in height, stem diameter and number of leaves of $S$. biafrae for the different treatments is shown in Figure 1, 2 and 3 respectively. The higher mean values of S. biafrae heights were observed at the weeks (1-5) for T4 (17.11-22.88 cm), T5 (18.22-23.68 $\mathrm{cm})$ and T6 $(18.89-27.01 \mathrm{~cm})$ when compared to T1 $(15.88-22.75)$, T2 $(16.38-23.75 \mathrm{~cm})$ and T3 (17.01 $26.13 \mathrm{~cm})$. Results indicated significant difference $(\mathrm{p}<$ 0.05 ) between the control (T0), T3 and T6 for all the weeks after planting (Figure 1). The mean plant height for all treatments increased with time (Figure 1). T3 (topsoil with the addition of $15 \mathrm{~g}$ of organic fertilizers) gave the greatest mean plant height from week6 to week 8 which is followed by T6 (topsoil with the addition of $15 \mathrm{~g}$ of inorganic fertilizers) while the least mean plant height was from the control (T1).

The highest mean values at early weeks of growth in T4, T5 and T6 when compared to T2, T1 and T3 may be attributed to availability of nitrogen from inorganic fertilizers as compared to nitrogen from organic fertilizers that must be decomposed and mineralized before it's been available to plants (Shisanya et al. 2009). Thus, causing gradual release of organic nutrients to crops (Okoroafor et al., 2013). 


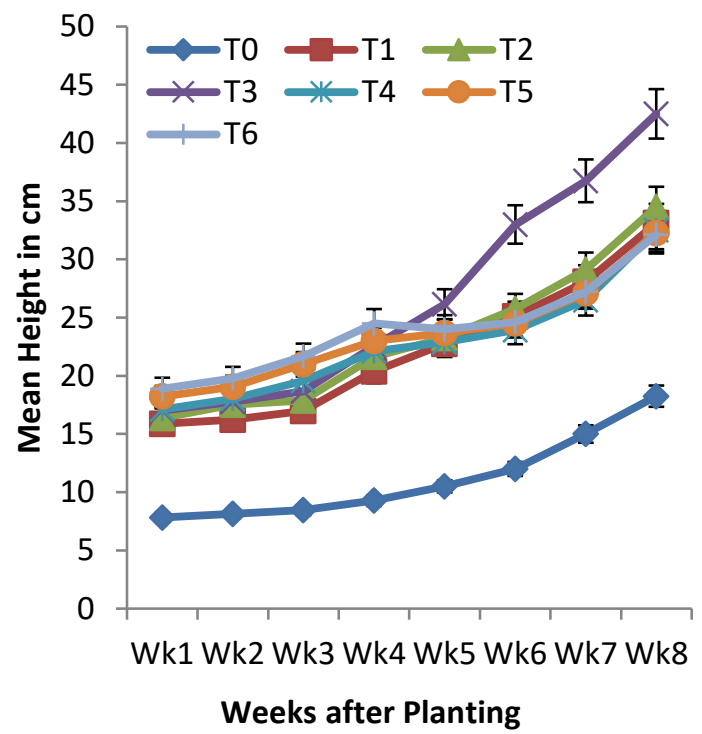

Fig 1: Mean heights of S. biafrae

The number of leaves increased with time for all treatments (Figure 2). The mean number of leaves for all the treatments for weeks after plantings were $\mathrm{T} 0$ (5.00-26.00), T1 (7.00-31.00), T2 (7.81-33.00), T3 (8.00-37.00), T4 (7.89-25.00), T5 (8.78-31.55) and T6 (9.00-33.50). Significant differences were observed among the treatments (Figure 2). Results indicated that treatments from organic fertilizers had the highest number of leaves followed by inorganic fertilizer while control had the least values. Significant difference was also noticed among the treatments $(p<0.05)$. The mean stem diameters of S. biafrae seedlings increase with weeks (Figure 3). The mean stem diameters in the treatments used in this study from week 1 to week 8 were as follows: T0 (3.50$5.90 \mathrm{~cm})$, T1 $(3.81-7.92 \mathrm{~cm})$, T2 $(3.95-8.22 \mathrm{~cm})$, T3 $(4.91-8.99 \mathrm{~cm}), \mathrm{T} 4(4.11-6.01 \mathrm{~cm}), \mathrm{T} 5(4.52-7.57 \mathrm{~cm})$ and T6 $(5.11-7.88 \mathrm{~cm})$.

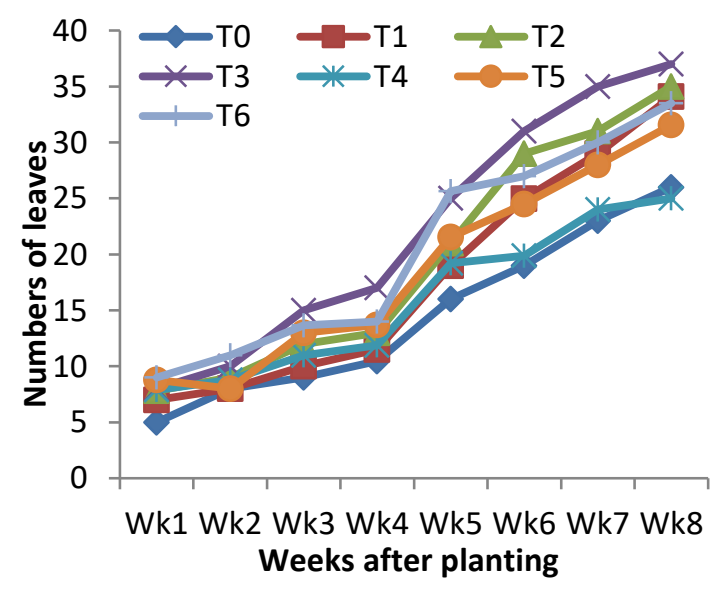

Fig 2: Mean Number of leaves of S. biafrae

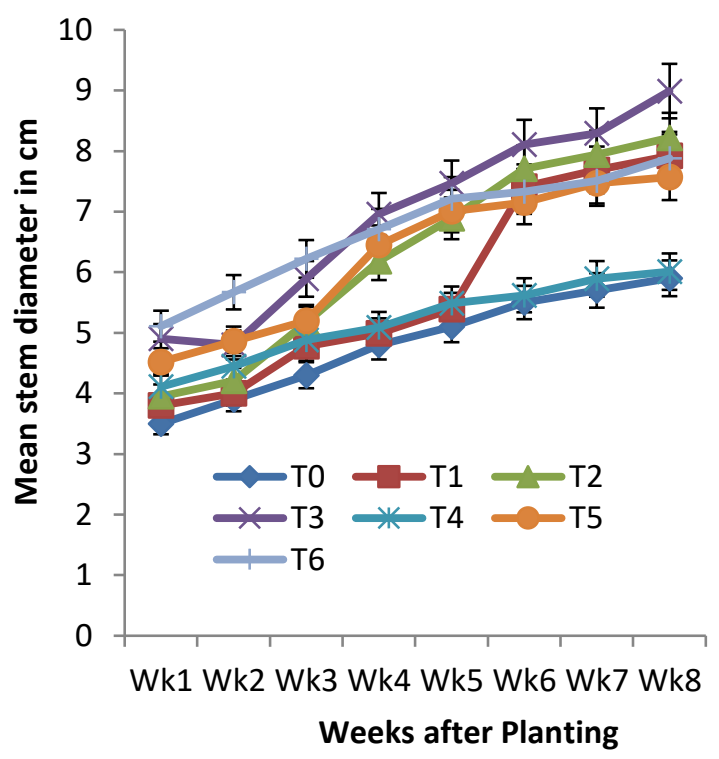

Fig 2: Mean Stem diameter of S. biafrae

It was observed that treatments from organic fertilizer mixture had the highest mean values followed by those from inorganic fertilizer while that of control had the lowest mean value from week 6 to week 8 . Significant difference was also noticed among the treatments $(\mathrm{p}<0.05)$.

Generally, the significant effect of both poultry manure and NPK 15:15:15 fertilizer application mixture may be attributed to low fertility of the topsoil used for the study. This is similar to the findings of Makinde et al (2007) and Uko et al (2009) and they attributed their findings to response of plants to application of fertilizer in the soil as it increases their nutrient status. Organic fertilizer apart from releasing nutrient elements to the soil has also been shown to improve other soil chemical and physical properties which enhance crop growth and development (Dauda et al., 2008; Uko et al., 2009). This may be accountable for the superior performance recorded in S. biafrae seedlings that had poultry manure mixture than inorganic fertilizer and those form control treatment. Also, the higher increase in the growth parameter sup to six weeks of planting in inorganic fertilizers (NPK 15:15:15) mixture when compared to poultry manure may be attributed to effective and increase in the consumption of inorganic fertilizers as a result of reduction, leaching and losses of nutrients (Ullah et al., 2008; Idem et al., 2012). This can also be due to decomposition and mineralization nature of organic manure before it's been available to plants (Shisanya et al., 2009), thus causing gradual release of organic nutrients to crops (Okoroafor et al., 2013). The significant performance of organic and inorganic fertilizers on the plants over the control could be due 
to presence of essential nutrient elements associated with high photosynthetic activities that can promote vigorous growth (Dauda, et al., 2008; Idem et al., 2012). However, the overall results indicated that $S$. biafrae grown in poultry manure showed significant performance than other growing mixtures and this may suggest presence of useful soil nutrients that are needed for plant growth.

Conclusion: The application of poultry and NPK fertilizer showed significant effect on the height, leaf production and stem diameters of S. biafrae. The results revealed that $\mathrm{S}$. biafrae responded healthy to the application of organic manure compared to inorganic fertilizer and control treatment in the study. Thus, the application of organic manure is adequate for maximum performance and growth of S. biafrae plant and inorganic fertilizer may be used in the absence of organic manure.

\section{REFERENCE}

Adebooye, OC. (2004). Solaneciobiafrae (Oliv. \& amp; Hiern) C. Jeffrey. [Internet] Record from PROTA4U. In: Grubben, GJH; Denton, OA (ed) PROTA (Plant Resources of Tropical Africa. Ressourcesvégétales de l'Afriquetropicale) Wageningen, Netherlands

Adelakun, SA; Babatunde, O; Olusegun, O; Oyebowale, OO. (2018). Role of Aqueous Crude Leaf Extract of Senecio Biafrae Combined with Zinc on Testicular Function of Adult Male Sprague Dawley Rats. J. Family Reprod. Health. 12(1): $8-17$

Bakht, J; Shafi, M; Jan, MT; Shah, Z. (2009). Influence of crop residue management, cropping system and $\mathrm{N}$ fertilizer on soil $\mathrm{N}$ and $\mathrm{C}$ dynamics and sustainable wheat (Triticumaestivum L.) production. Soil Till. Res. 104:233-240

Chang, E; Chung, R; Tsai, YH. (2007). Effect of different application rates of organic fertilizer on soil enzyme activity and microbial population. Soil Sci. Plant Nutr.53:132-140

Chen, D; Yuan, L; Liu, Y; Ji, J; Hou, H. (2017). Longterm application of manures plus chemical fertilizers sustained high rice yield and improved soil chemical and bacterial properties. Eur. J. Agron.90:34-42

Cui, X; Zhang, Y; Gao, J; Peng, F; Gao, P (2018). Long-term combined application of manure and chemical fertilizer sustained higher nutrient status and rhizospheric bacterial diversity in reddish paddy soil of Central South China. Sci. Rep. 8:111

Dantata, IJ (2011). Appraisal of the impact of nutrient sources on okra fruits yield. J. Sustain. Develop. 8(1/2):75-83.

Dauda, S. N., Ajayi, F. A. and Ndor, E. (2008): Growth and yield of water melon (Citrulluslanatus) as affected by poultry manure application J. Agric. Soc. Sci. 4: $121-124$

FAO (2004): Scaling soil nutrient balances. FAO Fertilizer and Plant Nutrition Bulletin No. 15. Rome

Gong, W; Yan, X; Wang, J; Hu, T; Gong, Y. (2008). Long-term manuring and fertilization effects on soil organic carbon pools under a wheat-maize cropping system in North China Plain. Plant Soil. 314:67-76

Idem, NU; Ikeh, AO; Asikpo, NS; Udoh, EI. (2012). Effect of organic and inorganic fertilizer on growth and yield of fluted pumpkin (Telfaria occidentialis, hook f.) in Uyo, Akwa Ibom State, Nigeria. J. Agric. Soc. Res.12(2):75-84

Li, X; Guo, J; Dong, R; Ahring, B.K; Zhang, W (2016), Properties of plant nutrient: Comparison of two nutrient recovery techniques using liquid fraction of digestate from anaerobic digester treating pig manure. Sci. Total Environ.544:774781

Mahmood, F; Khan, I; Ashraf, U; Shahzad. T; Hussaim, S; Shahid, M; Abid, M; Ullah, S. (2017). Effects of organic and inorganic manures on maize and their residual impact on soil physicochemical properties J. Soil Sci. Plant Nut. 17 (1):22-32

Makinde, EA; Ayoola, OT; Akande, MO. (2007). Effects of organic-mineral fertilizer application on the growth and yield of "egusi" melon (Citrullus vulgaris L.). Austr. J. Basic appli. Sci. 1(1): $15-19$

Ning, C; Gao, P; Wang, B; Lin,W; Jiang, N; Cai, K (2017). Impacts of chemical fertilizer reduction and organic amendments supplementation on soil nutrient, enzyme activity and heavy metal content. J. Integr. Agric. 16:1819-1831

Okoroafor, I; Okelola, E; Edeh, O; Nemehute, V; Onu, C; Nwaneri, T; Chinaka, GE (2013). Effect of 
organic manure on the growth and yield performance of Maize in Ishiagu, Ebonyi State, Nigeria. IOSR J. Agric. Vet.Sci.5:28-31

Palm, C. A. (1995): Contribution of agroforestry trees to nutrient requirements of intercropped plants. Agrofor. Sys.30:105-124

Prasithikhet, J; Mongkolporn, P, Sritanan, V; Sonmuang, P (1993): Use of organic and inorganic fertilizers in farmer's rice fields in the Northeast Parkisthan. Soil. Manage. Abstracts.5 (2):145-155

Shisanya, CA; Mucheru, MW; Mugendi, DN; Kung'u, JB (2009). Effect of organic and inorganic nutrient source on soil mineral nitrogen and maize yields in central highlands of Kenya. Soil Till. Res.103:239-246

Sun, R; Zhang, X; Guo, X; Wang, D; Chu, H (2015). Bacterial diversity in soils subjected to long-term chemical fertilization can be more stably maintained with the addition of livestock manure than wheat straw. Soil Biol. Biochem.88:9-18
Uko, AE; Udo, IA; Shiyam, JO (2009) Optimizing poultry manure rates for two okra (Abelmoschhus esculentus) varieties in a warm wet climate. $J$. Agric. Biotech.Ecol.2 (3) $273-285$

Ullah, MS; Islam, MS; Islam, MA; Haque, T (2008). Effects of organic manure and chemical fertilizers on the yield of brinjal and soil properties. $J$. Banladesh Agricultural University. 6(2): 271 276

Zhang, P; Chen, X; Wei, T; Yang, Z; Jia, Z; Yang, B (2016). Effects of straw incorporation on the soil nutrient contents, enzyme activities, and crop yield in a semiarid region of China. Soil Till. Res.160: 65-72 